\title{
Performance evaluation of coating materials and process parameters optimization for surface quality during turning of AISI 304 austenitic stainless steel
}

\author{
M. Kaladhar ${ }^{1 *}$, K. Venkata Subbaiah ${ }^{2}$, Ch. Srinivasa Rao ${ }^{2}$ \\ ${ }^{1}$ Department of Mechanical Engineering, Praveenya Institute of Marine Engineering Visakhapatnam-531 162, Andhra Pradesh, INDIA \\ ${ }^{2}$ Department of Mechanical Engineering, Andhra University, Visakhapatnam-530 003, Andhra Pradesh, INDIA \\ "Corresponding Author: e-mail: kaladhar2k@gmail.com
}

\begin{abstract}
Austenitic stainless steels are a widely used group of stainless steels. Problems have been reported by users during machining due to its low thermal conductivity, high work hardening, high strength, and high ductility. These made it difficult to machine the materials. The aim of the present study is to investigate the influence of Pressure Vapour Deposition (PVD) and Chemical Vapour Deposition (CVD) coated cemented carbide inserts on the surface quality of the work piece when turning on AISI 304 austenitic stainless steel work pieces, on computer numerical controlled (CNC) lathe. Taguchi's Design of Experiments approach (DOE) is used to analyze the effect of process parameters on surface roughness to obtain their optimal setting. The analysis of variance (ANOVA) is employed to analyze the influence of process parameters during turning. The results have shown that the improvement in average surface finish is obtained when machining with PVD coated insert $(1.13 \mu \mathrm{m})$. The nose radius is the most significant process parameter $(62.88 \%$ contribution) when turning with PVD insert. The cutting speed is the most significant factor $(37.84 \%$ contribution) when turning with CVD insert. Optimal ranges of surface roughness values are also predicted.
\end{abstract}

Keywords: CVD coated insert, Surface roughness, AISI 304 austenitic stainless steel, Taguchi approach, ANOVA

\section{Introduction}

Surface integrity is a significant quality measure for evaluating the productivity of the machine tools and mechanical parts. Surface quality is influenced by various factors such as tool geometry cutting parameters, work materials variables, cooling lubrication environment etc. Many experimental studies have been conducted to explore the effects of cutting conditions on the surface roughness of various work piece materials (Aman Aggarwal et al., 2008; Anirban Bhattacharya et al., 2009; Anthony and Adithan 2009; Mahapatra SS et al., 2006). Achieving good surface finish of difficult-to-machine materials is a tough task. Many problems have been reported by users during its machining (O'Sullivan and Cotterell 2002). In this regard, many efforts have been put to improve its machinability, among which, application of hard coatings on tools by PVD and CVD is one of the effective ways. It is proved that coated tools performance is better than the uncoated tools. Today around $70 \%$ of the tools are cemented carbide coated tools, used in various manufacturing industries. These hard coatings increase tool life, allow improved and more consistent surface finish of the machined work piece (Endrino et al., 2006). Especially these hard coatings are very much useful to improve the machinability of difficult-to-machine materials such as austenitic stainless steel.. The tendency of high work hardening, high strength, low thermal conductivity makes austenitic stainless steel difficult to machine.

Optimal setting of process parameters is a crucial aspect to improve the machinability of the materials. The availability of machining data from suppliers, engineering data book, experience of machine tool operators are not very scientific which further decreases productivity. Under these circumstances, optimal selection and implementation of machining parameters is necessary to enhance the productivity. 
The aim of the present experimental investigation is to evaluate the effects of the coating materials and determine the optimal levels of process parameters for optimizing the surface quality of AISI 304 austenitic stainless steel work piece by employing Taguchi's orthogonal array design and Analysis of Variance (ANOVA) using CVD and PVD coated tool on CNC lathe under dry environment. The AISI 304 austenitic stainless steel is the most widely used grade among all the grades of austenitic stainless steel. It is used for aerospace components and chemical processing equipment, for food, dairy, and beverage industries, for heat exchangers, and for the milder chemicals.

\subsection{Austenitic stainless steel machining}

The austenitic stainless steel is consumed in large volumes (72\%) among the other grades of stainless steels. Many of research works contributed their efforts to overcome poor machinability of austenitic stainless steels (Lin, 2008; Anthony and Adithan, 2009; Ciftci, 2006; Ozek et al., 2006; Al-Ahmari, 2007; Caydas and Ekici, 2010; Jahan et al., 2010; O'Sullivan and Cotterell, 2002; Korkut et al., 2004; Akasawa et al., 2003). The literature survey revealed that little attention has been focused to turn the AISI 304 austenitic stainless steel under different cutting parameters with different coated tools.

\section{Experimental Procedure}

Turning is a widely used material removal process from the surface of a rotating cylindrical work piece. The Computer numerical controlled (CNC) machines play a major role in modern machining industry to enhance product quality as well as productivity (Tian-Syung, 2009). The present experimental investigation was carried out according to the conditions given in Table 1. Taguchi specified $\mathrm{L}_{16}$ mixed level design (Table 4). The machining tests are carried out on the material in cylindrical form, 330 $\mathrm{mm}$ long and $50 \mathrm{~mm}$ diameter by two types of cutting inserts separately with two different nose radii on a Parishudh TC-250 CN, India, CNC lathe with a variable speed of up to $3250 \mathrm{rpm}$ and a power rating of $7.5 \mathrm{~kW}$. These work pieces cleaned prior to the experiments by removing $0.3 \mathrm{~mm}$ thickness of the top surface from each work piece in order to eliminate any surface defects and wobbling. As far as possible, the machining tests were performed as per the recommendations of ISO 3685. The surface roughness of machined surfaces has been measured by a Talysurf (Taylor Hobson, Surtronic 3+, UK) surface roughness tester. The chemical composition of AISI 304 is given in Table 3. The technical features of cutting inserts are given in the Table 2.

Table 1: Cutting parameters levels

\begin{tabular}{|l|c|c|c|c|}
\hline \multirow{2}{*}{ parameters } & \multicolumn{4}{|c|}{ Levels } \\
\cline { 2 - 5 } & 1 & 2 & 3 & 4 \\
\hline $\begin{array}{l}\text { Cutting } \\
\text { speed } \\
\text { (m/min) }\end{array}$ & 150 & 170 & 190 & 210 \\
\hline $\begin{array}{l}\text { Feed } \\
\text { (mm/rev) }\end{array}$ & 0.15 & 0.20 & 0.25 & 0.30 \\
\hline $\begin{array}{c}\text { Depth of } \\
\text { cut mm) }\end{array}$ & 0.5 & 1.0 & 1.5 & 2.0 \\
\hline $\begin{array}{c}\text { Nose } \\
\text { radius(mm) }\end{array}$ & 0.4 & 0.8 & --- & --- \\
\hline
\end{tabular}

Table 2: Properties of cutting inserts

\begin{tabular}{|c|c|c|c|}
\hline $\begin{array}{c}\text { Coating } \\
\text { method and } \\
\text { layers/substrate }\end{array}$ & $\begin{array}{c}\text { ISO } \\
\text { grade }\end{array}$ & $\begin{array}{c}\text { Geometric } \\
\text { form }\end{array}$ & $\begin{array}{c}\text { Manufacturer } \\
\text { and code }\end{array}$ \\
\hline $\begin{array}{c}\mathrm{CVD}(\mathrm{TiCN}- \\
\mathrm{Al}_{2} \mathrm{O}_{3^{-}} \\
\text {TiN)/Cemented } \\
\text { carbide }\end{array}$ & $\begin{array}{c}\mathrm{M} 15, \\
\mathrm{P} 25\end{array}$ & $\begin{array}{c}\mathrm{CNMG} \\
120404\end{array}$ & $\begin{array}{c}\text { Sandvik } \\
\text { GC2015 }\end{array}$ \\
\hline $\begin{array}{c}\mathrm{PVD}(\mathrm{TiAlN}- \\
\mathrm{TiN}) /\end{array}$ & $\mathrm{M} 15$, & $\mathrm{CNMG}$ & Sandvik \\
$\begin{array}{c}\text { Cemented } \\
\text { carbide }\end{array}$ & $\begin{array}{c}\mathrm{S} 15, \\
\mathrm{P} 25\end{array}$ & 120404 & $\mathrm{GC1025}$ \\
\hline
\end{tabular}

Table 3: Chemical composition of AISI 304

\begin{tabular}{cc}
\hline Elements & Composition(\%wt) \\
\hline $\mathrm{C}$ & 0.051 \\
$\mathrm{Si}$ & 0.412 \\
$\mathrm{Mn}$ & 1.351 \\
$\mathrm{Cr}$ & 18.275 \\
$\mathrm{Ni}$ & 8.473 \\
$\mathrm{Mo}$ & 0.301 \\
$\mathrm{Cu}$ & 0.318 \\
$\mathrm{Ti}$ & 0.005 \\
$\mathrm{~V}$ & 0.049 \\
$\mathrm{~W}$ & 0.003 \\
$\mathrm{Co}$ & 0.019 \\
$\mathrm{Nb}$ & 0.020 \\
$\mathrm{Fe}$ & Balance \\
\hline
\end{tabular}


Table 4: Experimental design using $\mathrm{L}_{16}$ mixed level array

\begin{tabular}{|c|c|c|c|c|c|c|}
\hline $\begin{array}{c}\text { Trail } \\
\text { no. }\end{array}$ & $\begin{array}{c}\text { Cutting } \\
\text { Speed } \\
\text { A }\end{array}$ & $\begin{array}{c}\text { Fee } \\
\text { d } \\
\text { B }\end{array}$ & $\begin{array}{c}\text { Depth of } \\
\text { Cut } \\
\text { C }\end{array}$ & $\begin{array}{l}\text { Nose } \\
\text { radius } \\
\mathrm{D}\end{array}$ & $\begin{array}{l}\text { Surface roughness } \\
\mathrm{R}_{\mathrm{a}}(\mu \mathrm{m}) \text { values } \\
\text { obtained when turning } \\
\text { with CVD insert }\end{array}$ & $\begin{array}{l}\text { Surface roughness } \\
\left.\mathrm{R}_{\mathrm{a}}(\mu \mathrm{m})\right) \text { values } \\
\text { obtained when } \\
\text { turning with PVD } \\
\text { insert }\end{array}$ \\
\hline 1 & 1 & 1 & 1 & 1 & 1.49 & 1.21 \\
\hline 2 & 1 & 2 & 2 & 1 & 1.02 & 0.95 \\
\hline 3 & 1 & 3 & 3 & 2 & 1.65 & 1.2 \\
\hline 4 & 1 & 4 & 4 & 2 & 0.96 & 1.06 \\
\hline 5 & 2 & 1 & 2 & 2 & 1.5 & 1.14 \\
\hline 6 & 2 & 2 & 1 & 2 & 1.93 & 1.13 \\
\hline 7 & 2 & 3 & 4 & 1 & 0.99 & 0.99 \\
\hline 8 & 2 & 4 & 3 & 1 & 0.96 & 0.96 \\
\hline 9 & 3 & 1 & 3 & 1 & 1.11 & 1.2 \\
\hline 10 & 3 & 2 & 4 & 1 & 1.1 & 1.01 \\
\hline 11 & 3 & 3 & 1 & 2 & 1.14 & 1.01 \\
\hline 12 & 3 & 4 & 2 & 2 & 1.67 & 1.05 \\
\hline 13 & 4 & 1 & 4 & 2 & 1.46 & 1.38 \\
\hline 14 & 4 & 2 & 3 & 2 & 1.53 & 1.6 \\
\hline 15 & 4 & 3 & 2 & 1 & 0.96 & 1 \\
\hline 16 & 4 & 4 & 1 & 1 & 1 & 1.2 \\
\hline
\end{tabular}

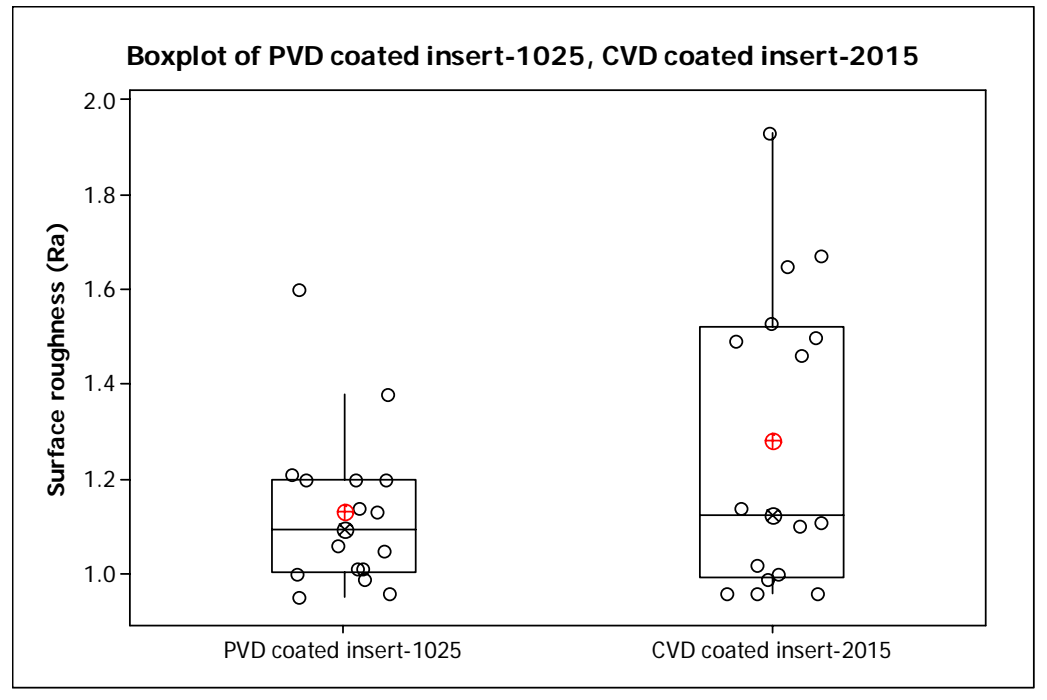

The regression equation $\mathrm{Ra}=1.43-0.149 *$ coating $\left[\mathrm{R}^{2}=8.3 \%\right]$

Figure 1: Box plot of average surface roughness values obtained by two types of coatings Cutting inserts 


\section{Results and discussions}

The Figure 1 showed that the values of average surface roughness are obtained by PVD and CVD coated inserts are $1.13 \mu \mathrm{m}$, $1.28 \mu \mathrm{m}$. A $13.27 \%$ improvement of surface roughness value has been observed when machining with PVD coated insert. In both inserts, top layer is TiN and the coating is carried out by means of PVD process on different substrates. The outer or top most layer of TiN has a certain characteristics such as tendency to reduce BUE, a higher coefficient of friction and thermal conductivity. These characteristics resulted in less thermal cracks, increases tool life and improves surface finish. The CVD deposits the coating at high temperature $\left(950-1059^{\circ} \mathrm{C}\right)$ results embrittlement of the cutting edge. This drawback is overcome in the PVD process. It offers lower deposition temperature of coating $\left(400-600^{\circ} \mathrm{C}\right)$ and a sharp cutting edge without any embrittlement effect which is very essential for machining of stainless steels (Soderberg et al., 2001). The PVD process has a record of proven performance of over CVD process due to its low coating temperature deposition (Jindal et al., 1999). The average surface roughness values (From Figure 3) obtained at the selected feed rates are observed in decreasing order. The values are followed as; $1.31 \mu \mathrm{m}$ at $0.15 \mathrm{~mm}, 1.28 \mu \mathrm{m}$ at $0.20 \mathrm{~mm}, 1.11 \mu \mathrm{m}$ at $0.25 \mathrm{~mm}, 1.10 \mu \mathrm{m}$ at $0.3 \mathrm{~mm}$. Here, a $19 \%$ improvement of surface roughness value has been achieved due to increase in the feed rate $50 \%$, from 0.15 to $0.3 \mathrm{~mm} / \mathrm{rev}$. From the Figure 2, it is observed that the increase in cutting speeds at $150 \mathrm{~m} / \mathrm{min}, 170 \mathrm{~m} / \mathrm{min} ; 210 \mathrm{~m} / \mathrm{min}$ except at $190 \mathrm{~m} / \mathrm{min}$ also increase the average surface roughness values from $1.193 \mu \mathrm{m}$ to $1.26 \mu \mathrm{m}$. The average surface roughness value obtained at $190 \mathrm{~m} / \mathrm{min}$ is $1.16 \mu \mathrm{m}$. The average surface roughness values (From Figure 4) obtained at the depth of cuts of $0.5 \mathrm{~mm}, 1.00$ $\mathrm{mm}, 1.5 \mathrm{~mm}$ and $2.00 \mathrm{~mm}$ are $1.26 \mu \mathrm{m}, 1.16 \mu \mathrm{m}, 1.27 \mu \mathrm{m}, 1.11 \mu \mathrm{m}$. The results obtained when turning with PVD coated tool has shown better performance in each and every level of cutting parameters than the results obtained with CVD coated tool (Table 7).

Numerous studies have been carried out to observe changes in surface roughness depending on process conditions in various types of work materials. Most of these indicated that a high feed rate, higher depth of cut, and lower cutting speed resulted increase in the surface roughness values. However, the present work did not obtain such results. The reason is that the surface finish is adversely affected by lower feed rates. A lower feed rate leads to the formation of BUE which is partly carried out by the chip and the rest is deposited on the work piece (Akasawa et al., 2003). This tendency is observed in the present work. The high toughness and high ductility of the difficult-to cut materials produces long continuous curly chips which results surface texture deterioration and adhesive wear enhancement. In the present work, long and stringy chips are produced at lower feed rates which result tearing of work piece during chip formation due to the trapping /accumulation of chips and chip curling back into the work material (Fig. 3). This tendency results deterioration of work piece surface roughness. Another possible reason for the deviation of the results from the fundamental theoretical values tendency is the complex deformation pattern of difficult-to- machine materials (Pawade and Joshi, 2011). These kinds of results are also observed in the previous studies when machining with difficult-to- cut materials (Lin, 2009; Taha et al., 2010; Basim et al., 2011; Pawade and Joshi, 2011).

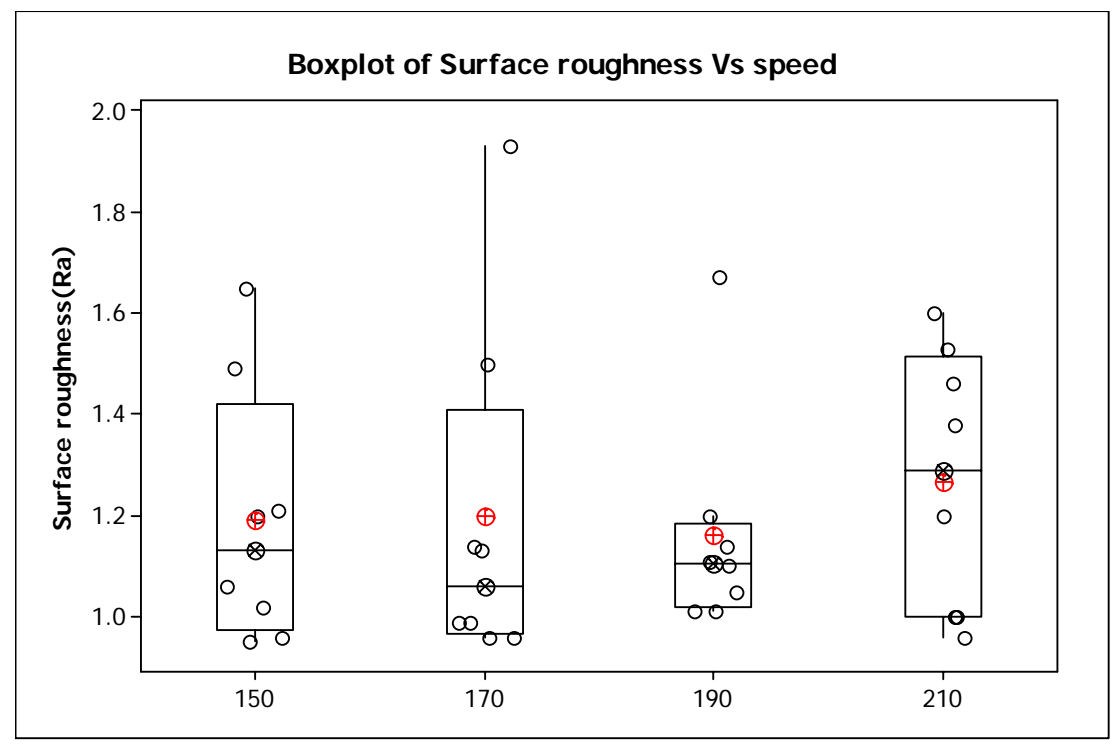

The regression equation $\mathrm{Ra}=1.04+0.00091^{*}$ speed $\left[\mathrm{R}^{2}=0.6\right]$

Figure 2: Box plot of average surface roughness values obtained by two Cutting inserts at different speeds 


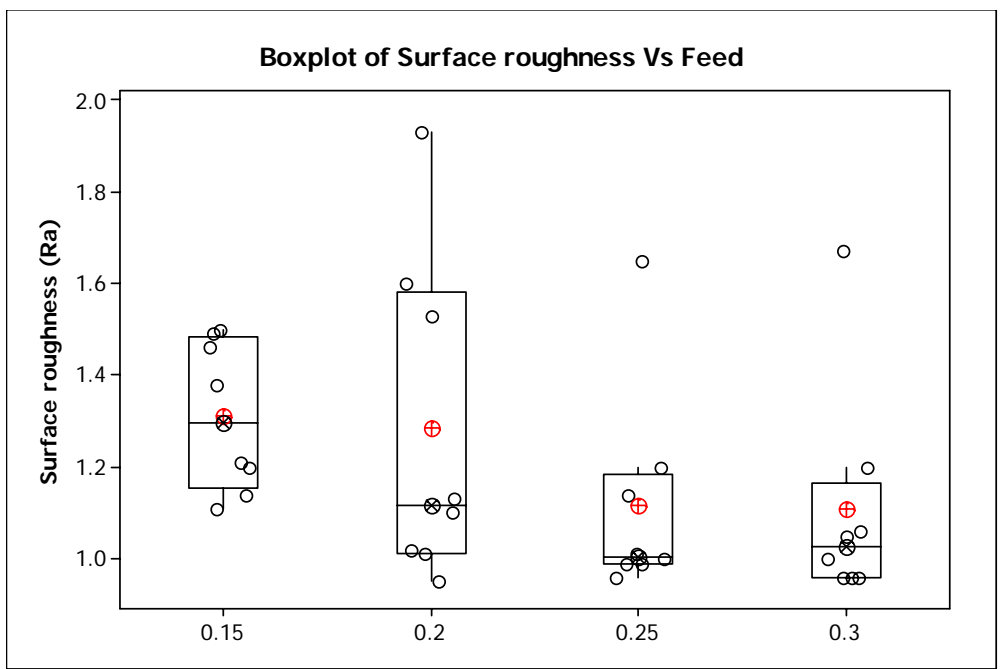

The regression equation $\mathrm{Ra}=1.55-1.56 *$ feed $\left[\mathrm{R}^{2}=11.3\right]$

Figure 3: Box plot of average surface roughness values obtained by two Cutting inserts at different feeds

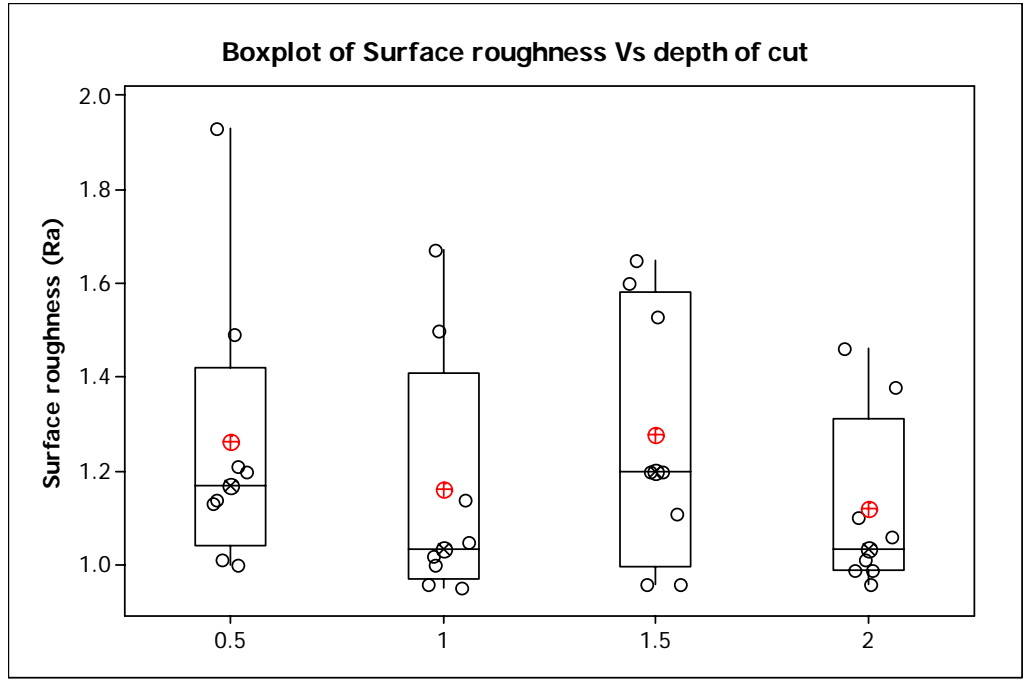

The regression equation $\mathrm{Ra}=1.29-0.0640 * \operatorname{doc}\left[\mathrm{R}^{2}=1.9\right]$

Figure 4: Box plot of average surface roughness values obtained by two Cutting inserts at different depths of cuts

Table 5: ANOVA Results for surface roughness values when turning with CVD insert

\begin{tabular}{ccccccc}
\hline Source & SS & DOF & MS & F & C (\%) & P-values \\
\hline Cutting speed & 0.02662 & 3 & 0.008873 & 0.087271 & 2.5993 & 0.9640 \\
Feed & 0.20762 & 3 & 0.069206 & 0.680659 & 20.2730 & 0.6000 \\
Depth of Cut & 0.14587 & 3 & 0.048623 & 0.478218 & 14.2434 & 0.7113 \\
Nose radius & 0.64401 & 1 & 0.644006 & 6.333943 & 62.8842 & 0.0372 \\
Error & 0.50838 & 5 & 0.101676 & & & \\
Total & 1.02412 & 15 & & & & \\
\hline
\end{tabular}


Table 6: ANOVA Results for surface roughness values when turning with PVD insert

\begin{tabular}{ccccccc}
\hline Source & SS & DF & MS & F & C (\%) & P-values \\
\hline Cutting speed & 0.1495 & 3 & 0.0498 & 4.788 & 37.838 & 0.0622 \\
Feed & 0.0904 & 3 & 0.0301 & 2.894 & 22.880 & 0.1411 \\
Depth of Cut & 0.0863 & 3 & 0.0287 & 2.759 & 21.842 & 0.1513 \\
Nose radius & 0.0689 & 1 & 0.0689 & 6.625 & 17.438 & 0.0341 \\
Error & 0.0524 & 5 & 0.0104 & & & \\
Total & 0.3951 & 15 & & & & \\
\hline
\end{tabular}

Table 7: Mean Values of Surface roughness

\begin{tabular}{|c|c|c|c|c|c|c|c|c|}
\hline \multirow{3}{*}{ Level } & \multicolumn{4}{|c|}{ CVD Coated Insert-2015 } & \multicolumn{4}{|c|}{ PVD Coated Insert-1025 } \\
\hline & \multicolumn{4}{|c|}{ Surface Roughness $\operatorname{Ra}(\mu \mathrm{m})$} & \multicolumn{4}{|c|}{ Surface Roughness $\operatorname{Ra}(\mu \mathrm{m})$} \\
\hline & A & $\mathrm{B}$ & $\mathrm{C}$ & $\mathrm{D}$ & A & $\mathrm{B}$ & $\mathrm{C}$ & $\mathrm{D}$ \\
\hline 1 & 1.280 & 1.390 & 1.390 & 1.079 & 1.105 & 1.233 & 1.138 & 1.065 \\
\hline 2 & 1.345 & 1.395 & 1.288 & 1.480 & 1.055 & 1.173 & 1.035 & 1.196 \\
\hline 3 & 1.255 & 1.185 & 1.313 & --- & 1.068 & 1.050 & 1.240 & ---- \\
\hline 4 & 1.238 & 1.148 & 1.128 & -- & 1.295 & 1.068 & 1.110 & --- \\
\hline
\end{tabular}

\subsection{Analysis of variance (ANOVA)}

The ANOVA is used to identify the significant process parameters more accurately by investigating the relative importance of process parameters (Ross, 1996). Table 5 shows the results of ANOVA for Ra when machining with CVD insert. It is observed that nose radius $(62.88 \%)$ is the most significant parameter followed by feed $(20.73 \%)$ when machining with CVD coated insert. A larger $\mathrm{F}$ value shows the greater impact on the machining performance characteristics (Ross, 1996). Larger F-values are observed for nose radius and feed. In case of PVD coated insert, (From Table 6), cutting speed (37.838\%) is the most significant factor followed by feed $(22.880 \%)$. whereas depth of cut and nose radius are less effective comparatively.

\subsection{Main effect plots analysis}

The analysis was made by a software package MINITAB 14. The main effect plots are shown in Figure 5 and Figure 6.These show the variation of individual response with the four parameters i.e. cutting speed, feed, depth of cut and nose radius separately. In the plots, the $\mathrm{x}$-axis indicates the value of each process parameter at two level and y-axis the response value. Horizontal line indicates the mean value of the response. The main effects plots are used to determine the optimal design conditions to obtain the optimum surface finish. Fig.3 shows the main effect plot for surface roughness of work piece when machined with CVD coated insert. The results showed that with the increase in cutting speed there is slight increment in $R_{a}$ value up to $170 \mathrm{~m} / \mathrm{min}$. Further, surface finish improves with increasing cutting speed. The lowest surface roughness value obtained at $210 \mathrm{~m} / \mathrm{min}$. Many works have been indicated that a high feed rate, high depth of cut and lower cutting speed would increase the surface roughness. But this is not occurred in the present work. This is due to the complex deformation characteristics of stainless steel during machining which may not be as similar to normal steels and alloys. This makes a difference. As the feed increases from $0.15 \mathrm{~mm} / \mathrm{rev}$ to 0.20 $\mathrm{mm} / \mathrm{rev}$ the surface roughness is increased slightly further decreases. Nose radius has proportional relation with Ra. At $210 \mathrm{~m} / \mathrm{min}$ speed, $0.3 \mathrm{~mm} / \mathrm{rev}$ feed, $3.00 \mathrm{~mm}$ depth of cut, the highest average surface roughness is recorded. The best average surface finish is obtained at $0.4 \mathrm{~mm}$ nose radius of cutting tool. In case of main effect plots of surface roughness of work piece when PVD coated is used for machining. As the speed increases the surface roughness value decreases up to $190 \mathrm{~m} / \mathrm{min}$ speed. And rise of surface roughness is observed at highest cutting speed $210 \mathrm{~m} / \mathrm{min}$. As the feed increases, surface roughness values decrease and rise occurred at $0.3 \mathrm{~mm} / \mathrm{rev}$. Lowest and highest surface roughness values obtained at $1.00 \mathrm{~mm}$ and $1.5 \mathrm{~mm}$ depth of cut. The surface roughness showed the up and down tendency with depth of cut. The Analysis of the results from the plots, lead to establish the optimal setting levels of process parameters. Hence, the combination of process parameters A3-B3-C4-D1 gives the minimum surface roughness when machined with CVD coated insert. Similarly, the combination of process parameters A2-B3-C2-D1 (From Table 4,6) produces minimum surface roughness when machined with PVD coated insert. 


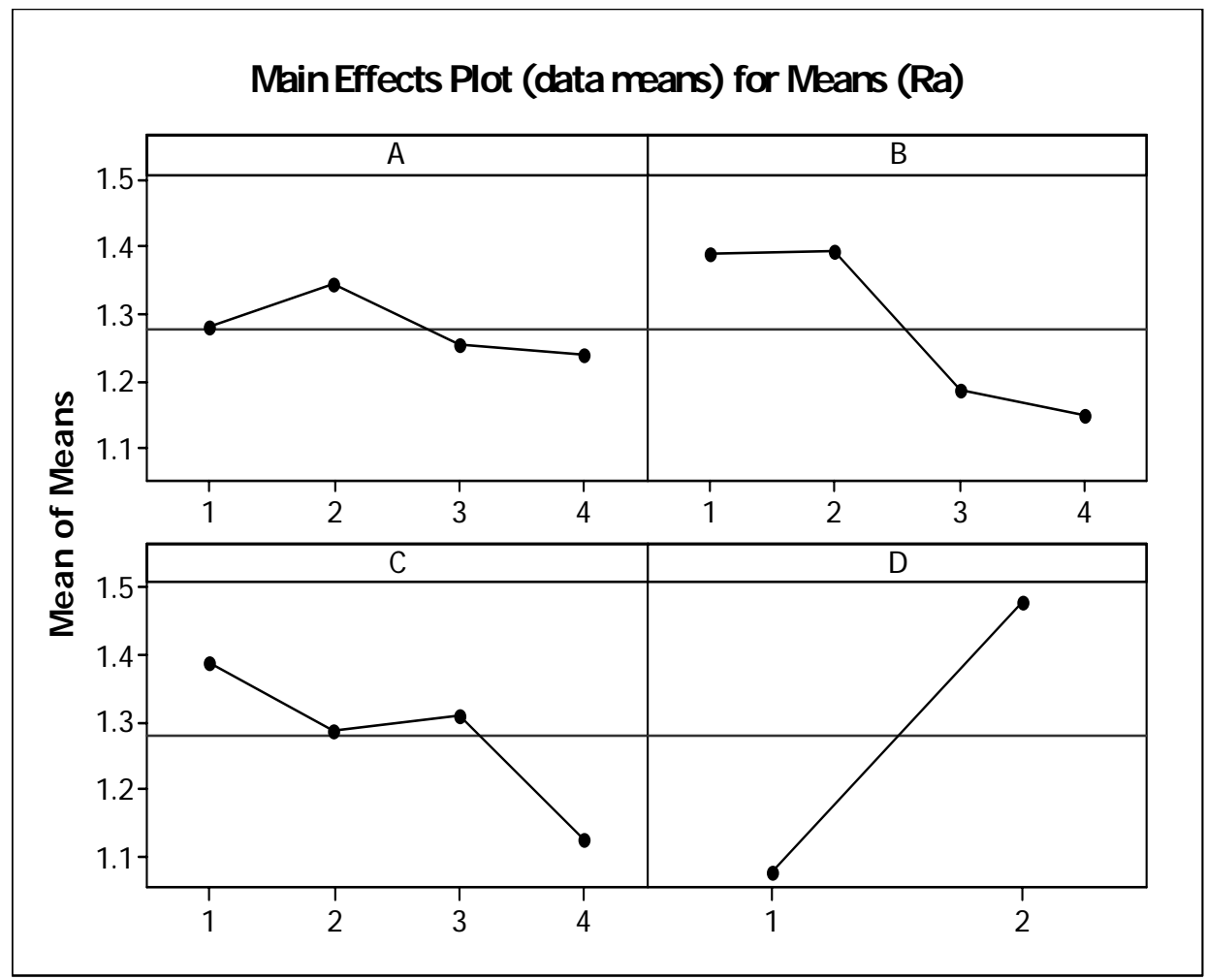

Figure 5: Main effect plot for Surface roughness Values when turning with CVD insert

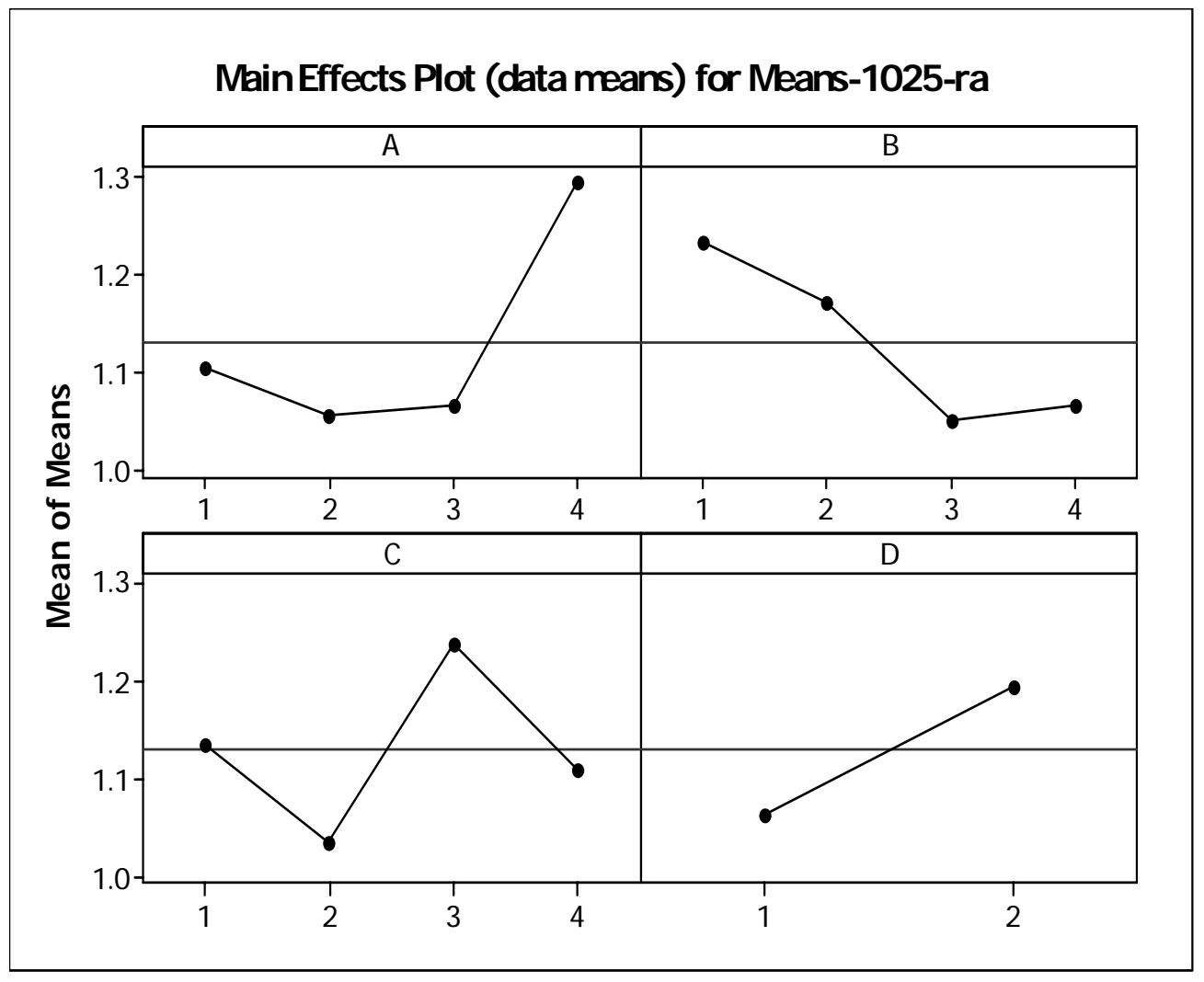

Figure 6: Main effect plot for Surface roughness Values when turning with PVD insert 
3.4 Prediction of optimal design

a) When turning with CVD insert

Performance of $\mathrm{R}_{\mathrm{a}}$ when the two most significant factors are at their better level (based on estimated average)

$$
\begin{aligned}
\bar{\mu}_{D_{1} C_{4}} & =\bar{D}_{1}+\bar{C}_{4}-\bar{T} \quad\left(\mathrm{D}_{1}, \mathrm{C}_{4} \text { values from Table } 7\right) \\
& =1.079+1.128-1.279=0.928(\text { From Table } 4, \bar{T}=1.279) \\
C I= & =\sqrt{\frac{F_{95 \%, 1, \text { doferror }}{ }^{*} V_{\text {error }}}{n_{\text {efficiency }}}} ;
\end{aligned}
$$

Where $n_{\text {efficiency }}=\mathrm{N} /(1+d o f)$ of all parameters associated to that level,

$$
n_{\text {efficiency }}=16 /(1+1+3)=3.2
$$

$V_{\text {error }}=0.101676$ (from Table 5), $F_{95 \%, 1,5}=6.61$ (From F-table)

$$
C I=\sqrt{6.61 * 0.101676 / 3.2} \quad=0.2561
$$

The predicted optimal range of $R_{a}$ at $95 \%$ confidence level is obtained as,

$$
\begin{aligned}
& 0.928-0.2561 \leq \bar{\mu}_{D_{1} C_{4}} \leq 0.928+0.2561 \\
& 0.6718 \leq \bar{\mu}_{D_{1} C_{4}} \leq 1.184
\end{aligned}
$$

b) When turning with PVD insert

Performance of $\mathrm{R}_{\mathrm{a}}$ when the two most significant factors are at their better level (based on estimated average)

$$
\begin{aligned}
& \bar{\mu}_{C_{2} A_{2}}=\bar{C}_{2}+\bar{A}_{2}-\bar{T} \quad\left(\mathrm{C}_{2}, \mathrm{~A}_{2} \text { values from Table } 7\right) \\
& =1.035+1.055-1.13=0.96(\text { From Table } 4, \bar{T}=1.13) \\
& C I==\sqrt{\frac{F_{95 \%, 1, \text { doferror }}{ }^{*} V_{\text {error }}}{n_{\text {efficiency }}}} ;
\end{aligned}
$$

Where $n_{\text {efficiency }}=\mathrm{N} /(1+d o f)$ of all parameters associated to that level,

$$
n_{\text {efficiency }}=16 /(1+1+3)=3.2
$$

$V_{\text {error }}=0.0104$ (from Table 6), $F_{95 \%, 1,5}=6.61$ (From F-table)

$$
C I=\sqrt{6.61 * 0.0104 / 3.2} \quad=0.146
$$

The predicted optimal range of $R_{a}$ at $95 \%$ confidence level is obtained as,

$$
\begin{gathered}
0.96-0.146 \leq \bar{\mu}_{C_{2} A_{2}} \leq 0.96+0.146 \\
0.814 \leq \bar{\mu}_{C_{2} A_{2}} \leq 1.106
\end{gathered}
$$

\subsection{Mathematical modeling}

A multiple linear regression models were developed for surface roughness using Minitab-14 software. The predictors are cutting speed, feed depth of cut and nose radius. The regression equation for surface roughness (CVD) before transformation of data = $1.16-0.0218^{*} \mathrm{~A}-0.0938 * \mathrm{~B}-0.0762 * \mathrm{C}+0.401 * \mathrm{D}[\mathrm{R}-\mathrm{Sq}=62.3 \%]$; The regression equation for surface roughness (PVD) before transformation of data $=0.912+0.0582 * \mathrm{~A}-0.0618 * \mathrm{~B}+0.0123 * \mathrm{C}+0.131 * \mathrm{D}$ [R-Sq $=48.8 \%$. The regression equation for surface roughness (CVD) after transformation of data $=0.129-0.0129 * \mathrm{~A}-0.0796 * \mathrm{~B}-0.0550 * \mathrm{C}+0.305 * \mathrm{D}[\mathrm{R}-\mathrm{Sq}$ $=64.7 \%]$; The regression equation for surface roughness $(\mathrm{PVD})$ after transformation of data $=-0.054+0.0458^{*} \mathrm{~A}-0.0525^{*} \mathrm{~B}+$ $0.0073 * \mathrm{C}+0.110 * \mathrm{D}[\mathrm{R}-\mathrm{Sq}=49.1 \%]$. 
The diagnostic checking has been performed through residual analysis for the developed models. From the figures 7 and 8 , it is observed that there is a violation (funnel/megaphone effect) of the assumption of homogeneity of variance. In order to stabilize the variances, transformation of data approach is applied. After the application of this approach, Figures 10-13 are now satisfactory. It can be concluded that all the values are within the CI level of $95 \%$. Hence, these values yield better results in future prediction. Figures 10 and 11 indicated that there is no obvious/ structureless pattern and unusual structure. From the Figures 10-13, it can be conclude that the residual analysis does not indicate any model inadequacy.

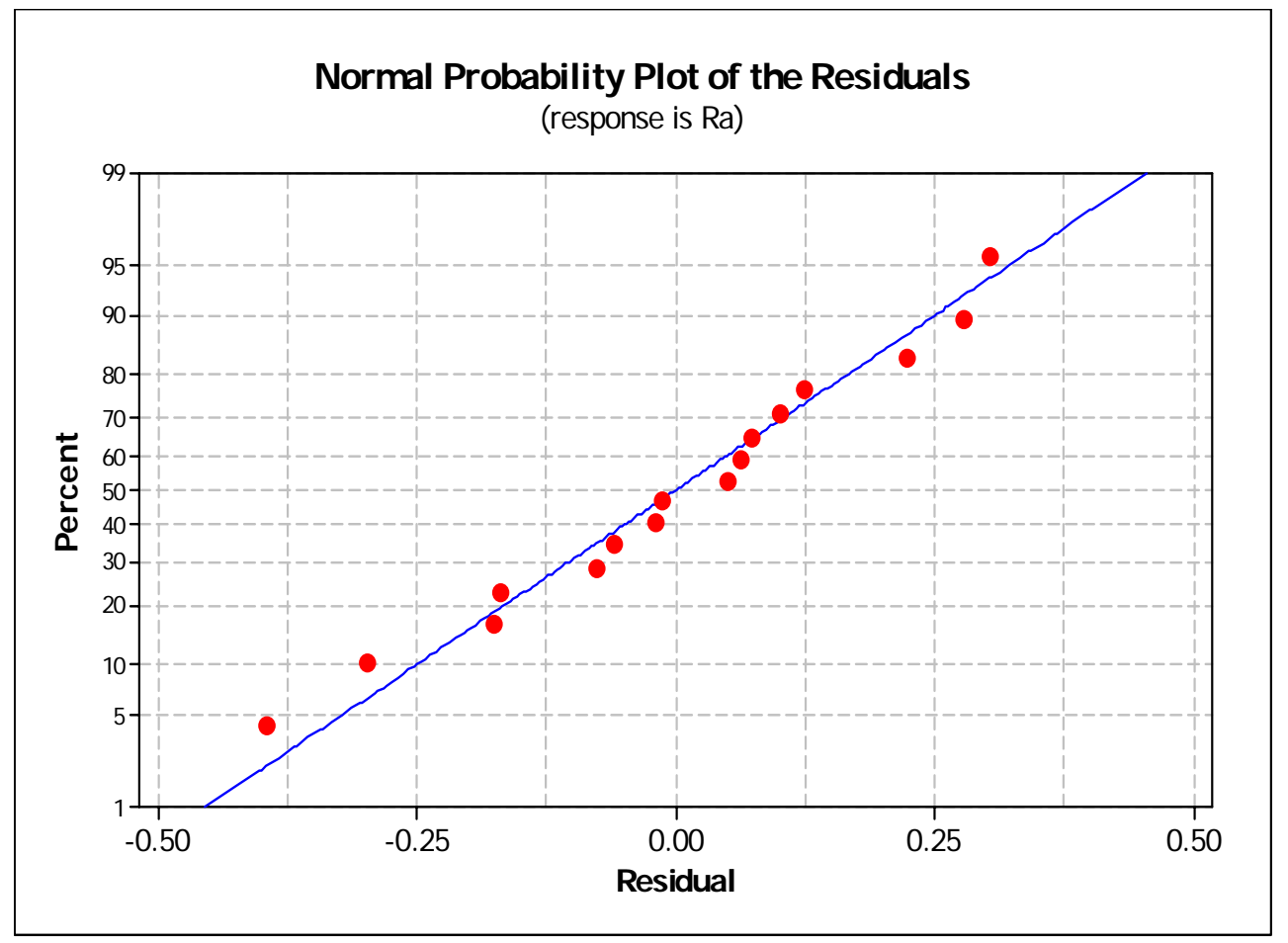

Figure 6: Normal Probability of the residuals for Surface roughness Values when turning with CVD insert

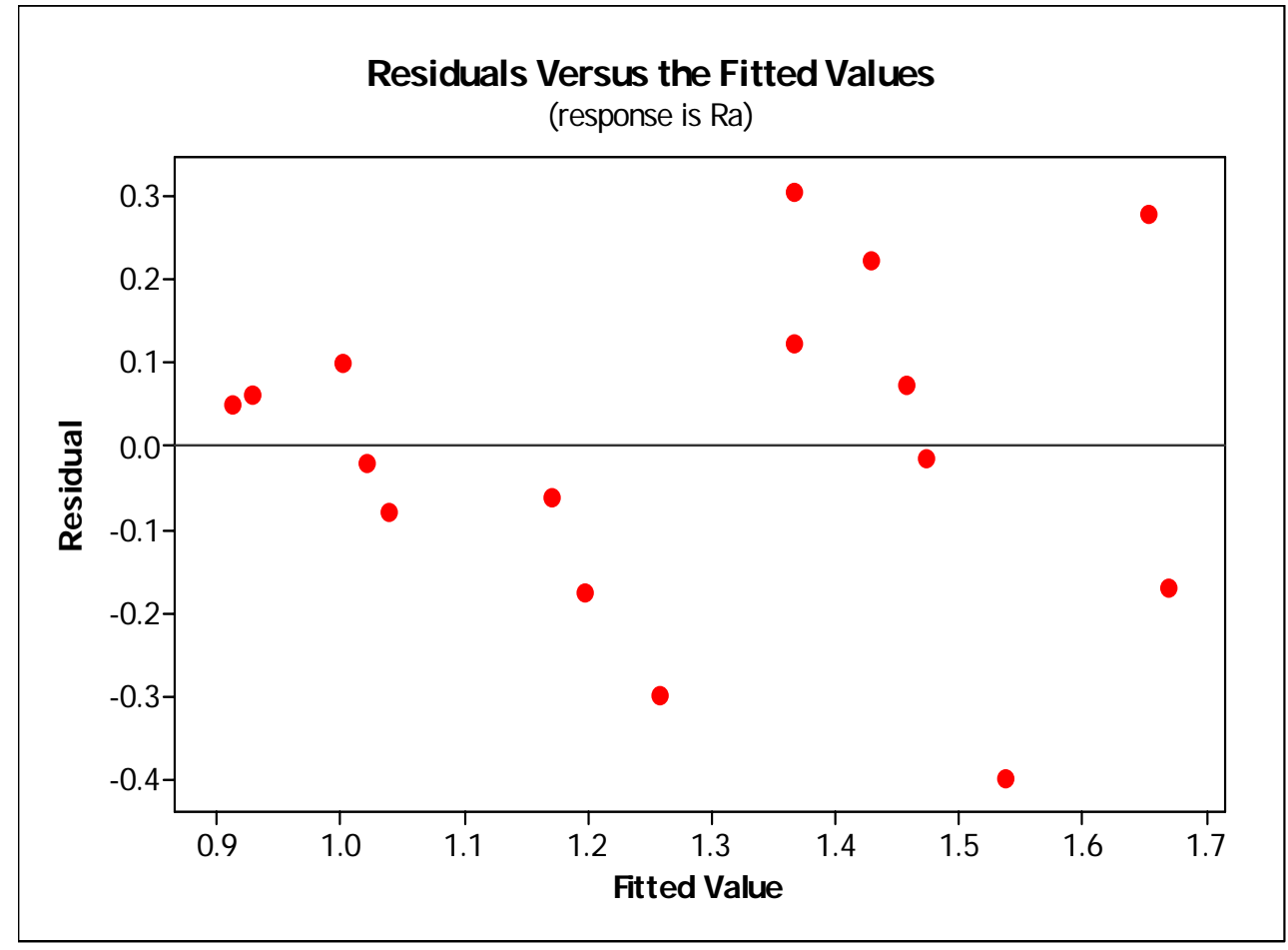

Figure 7: Residuals versus the fitted values for Surface roughness Values when turning with CVD insert 


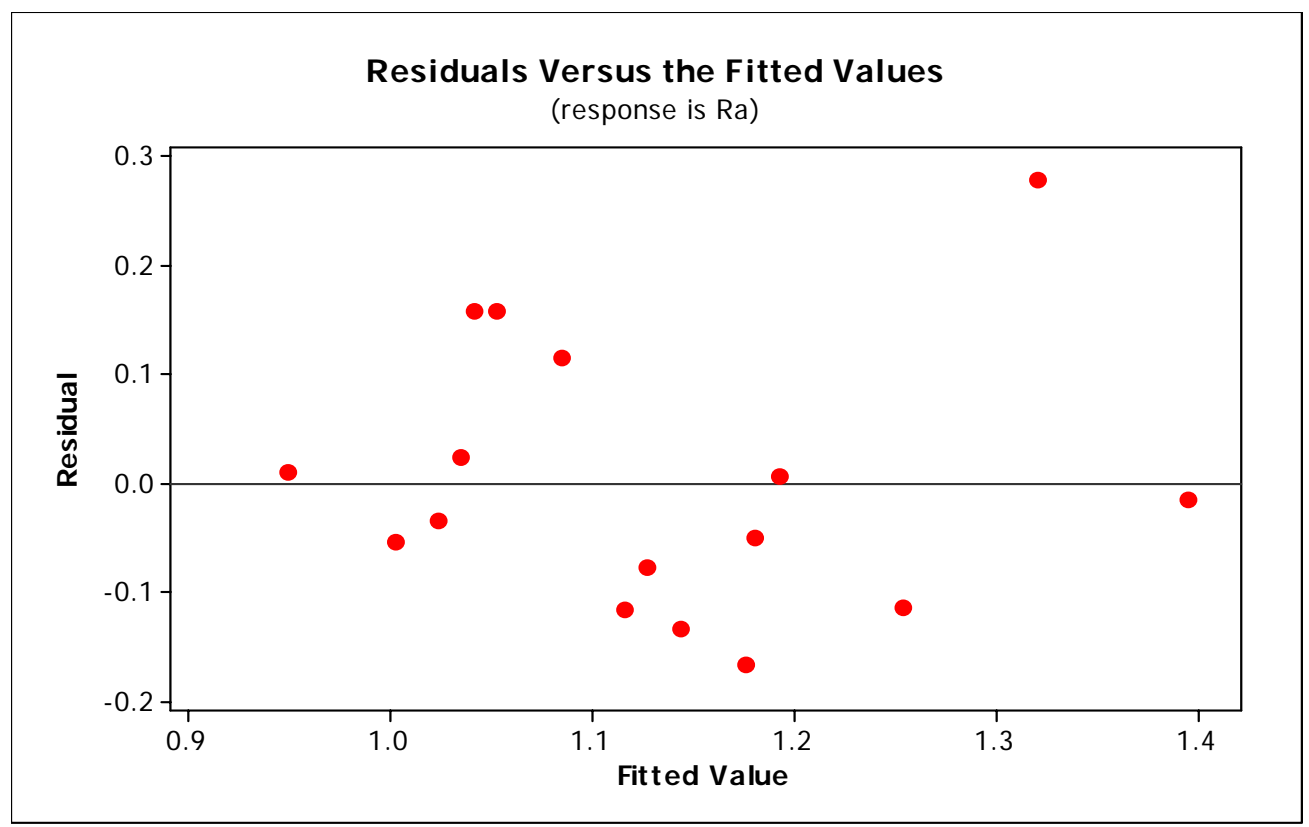

Figure 8: Residuals versus the fitted values for Surface roughness Values when turning with PVD insert

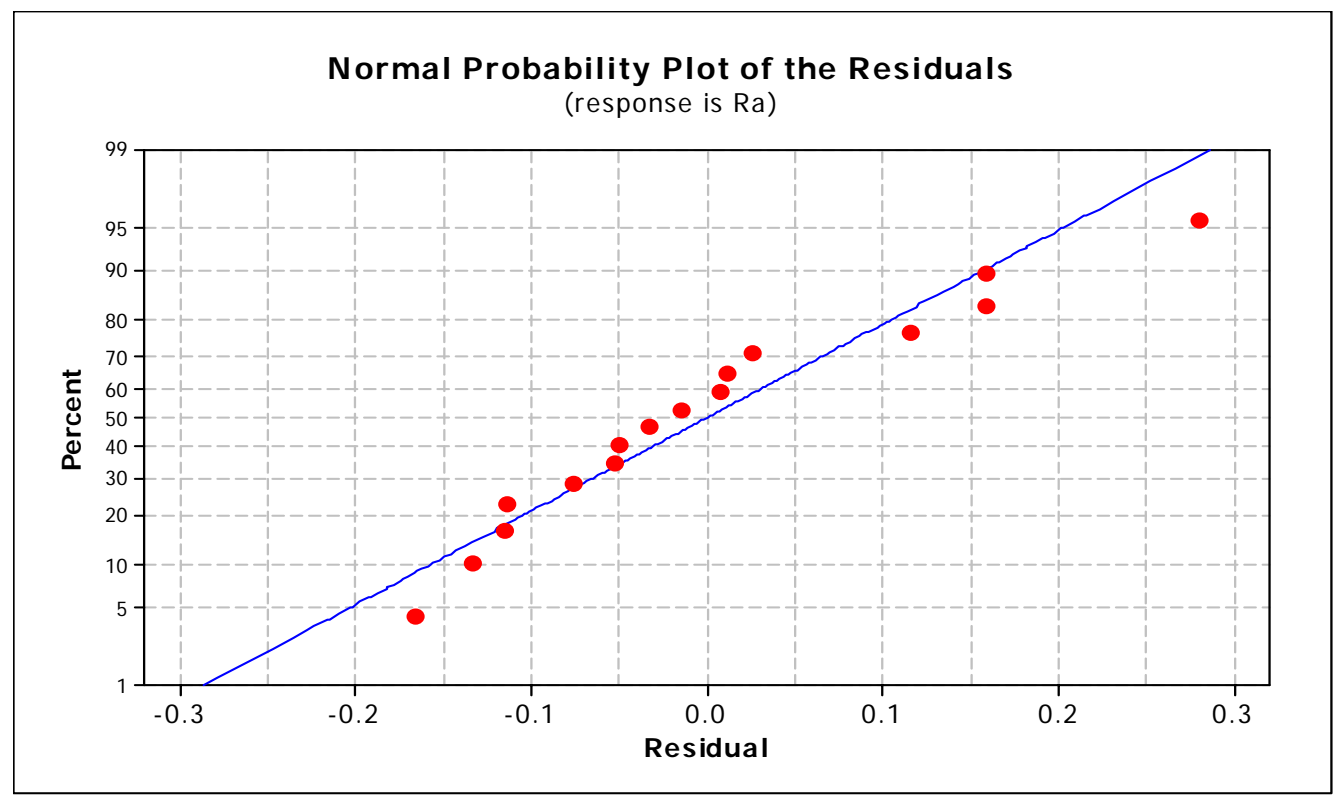

Figure 9: Normal Probability of the residuals for Surface roughness Values when turning with PVD insert 


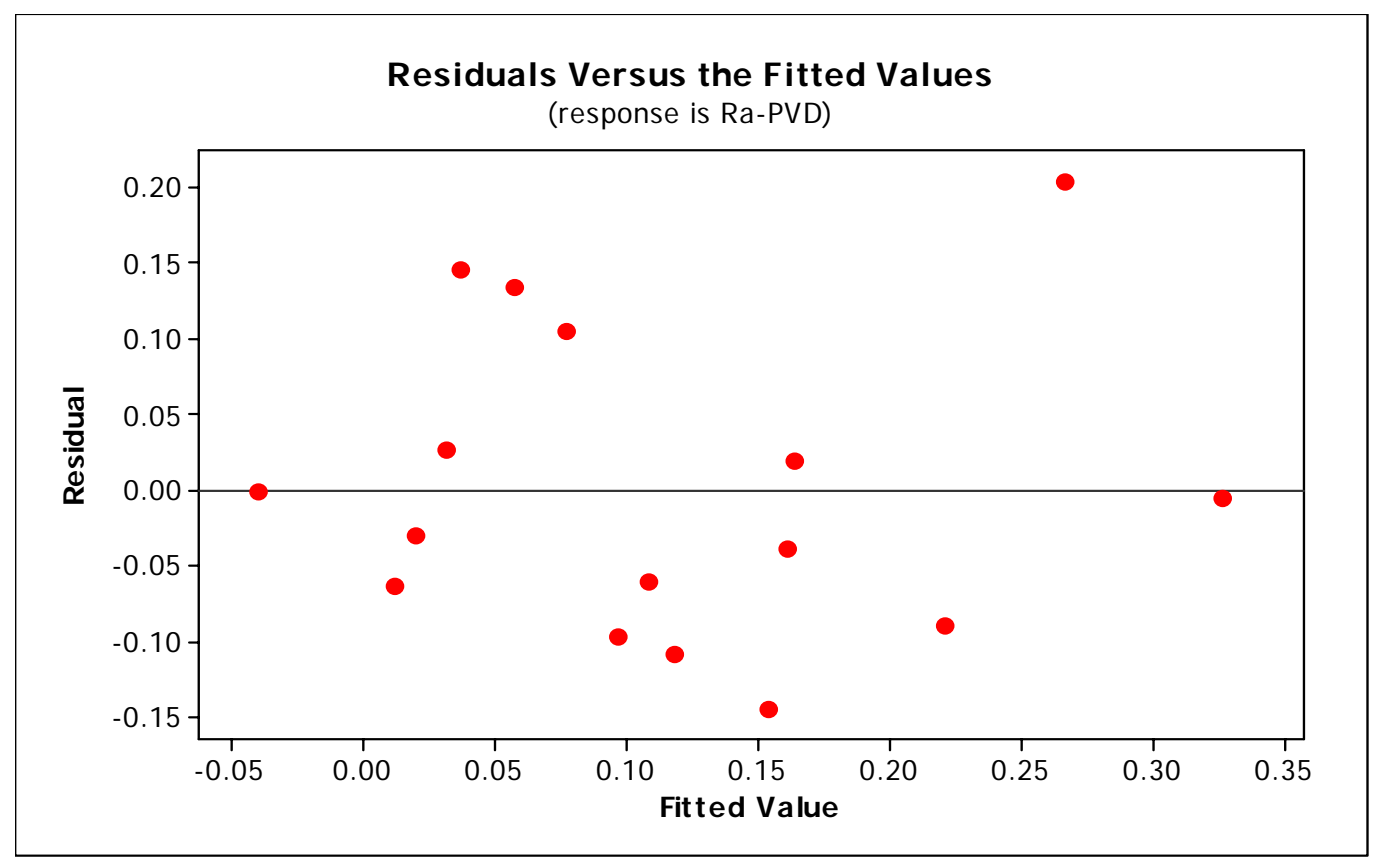

Figure 10: Normal Probability of the residuals for Surface roughness Values when turning with PVD insert (After data transformation)

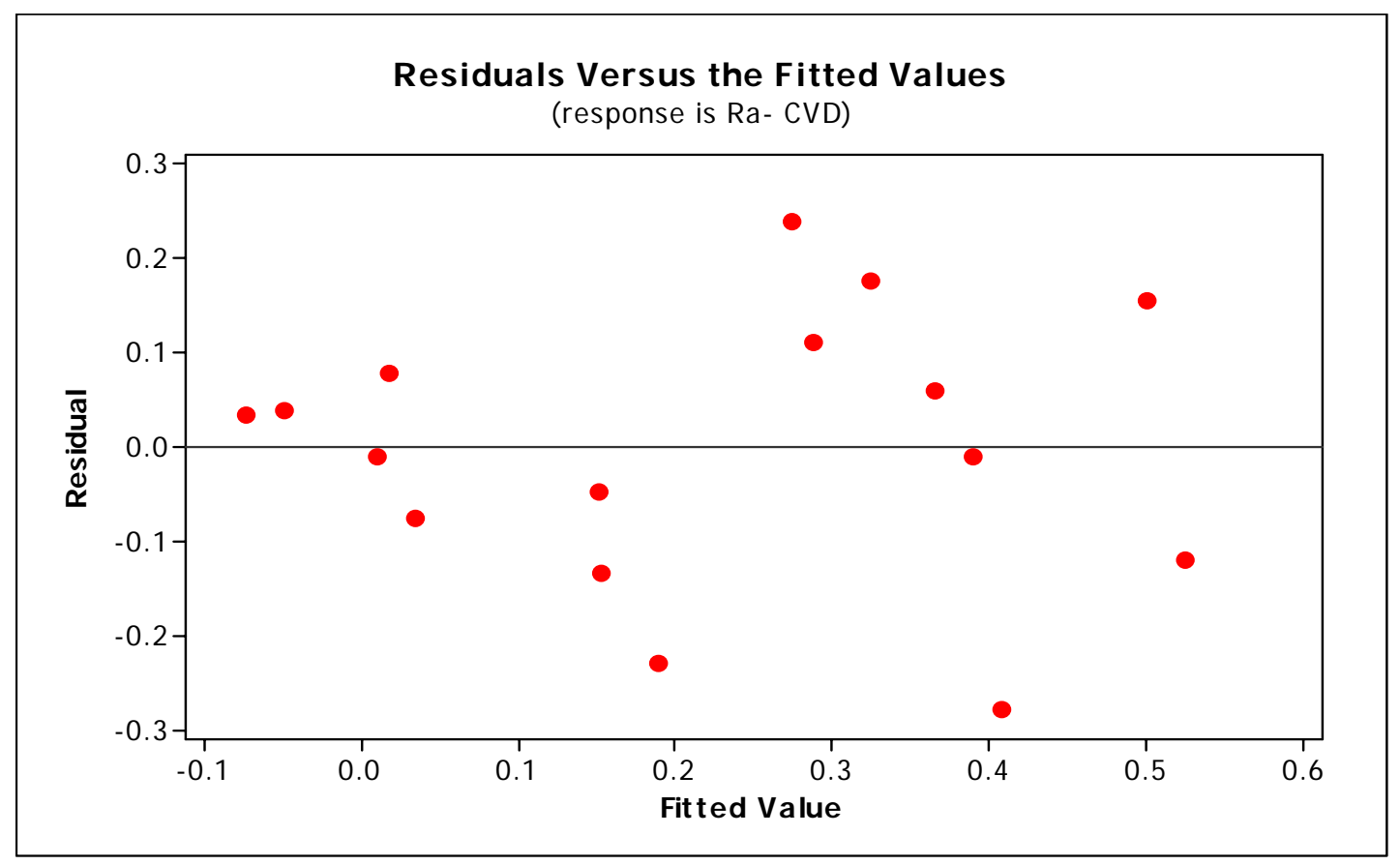

Figure 11: Residuals versus the fitted values for Surface roughness Values when turning with CVD insert (After data transformation) 


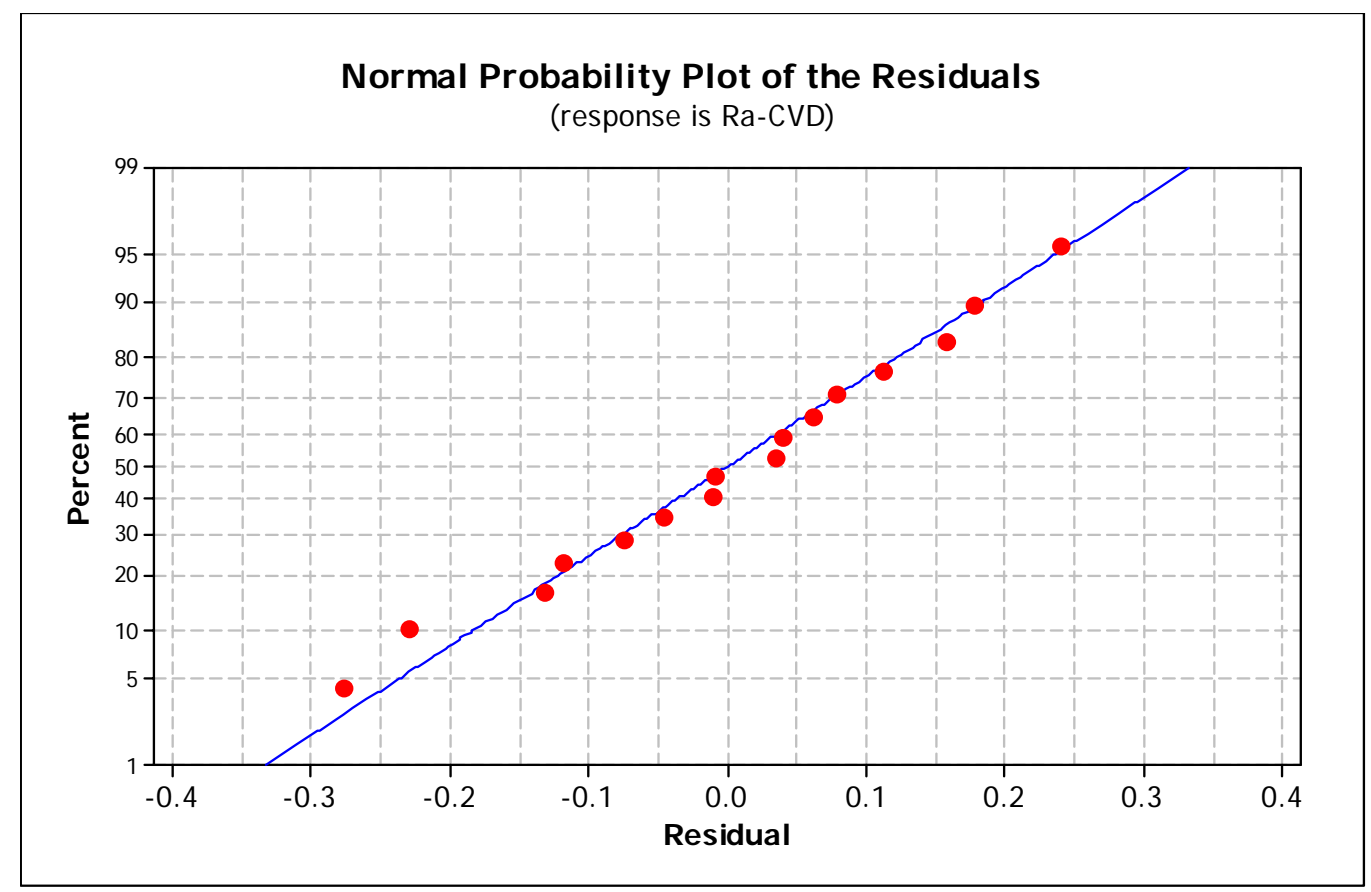

Figure 12: Normal Probability of the residuals for Surface roughness Values when turning with CVD insert (After data transformation)

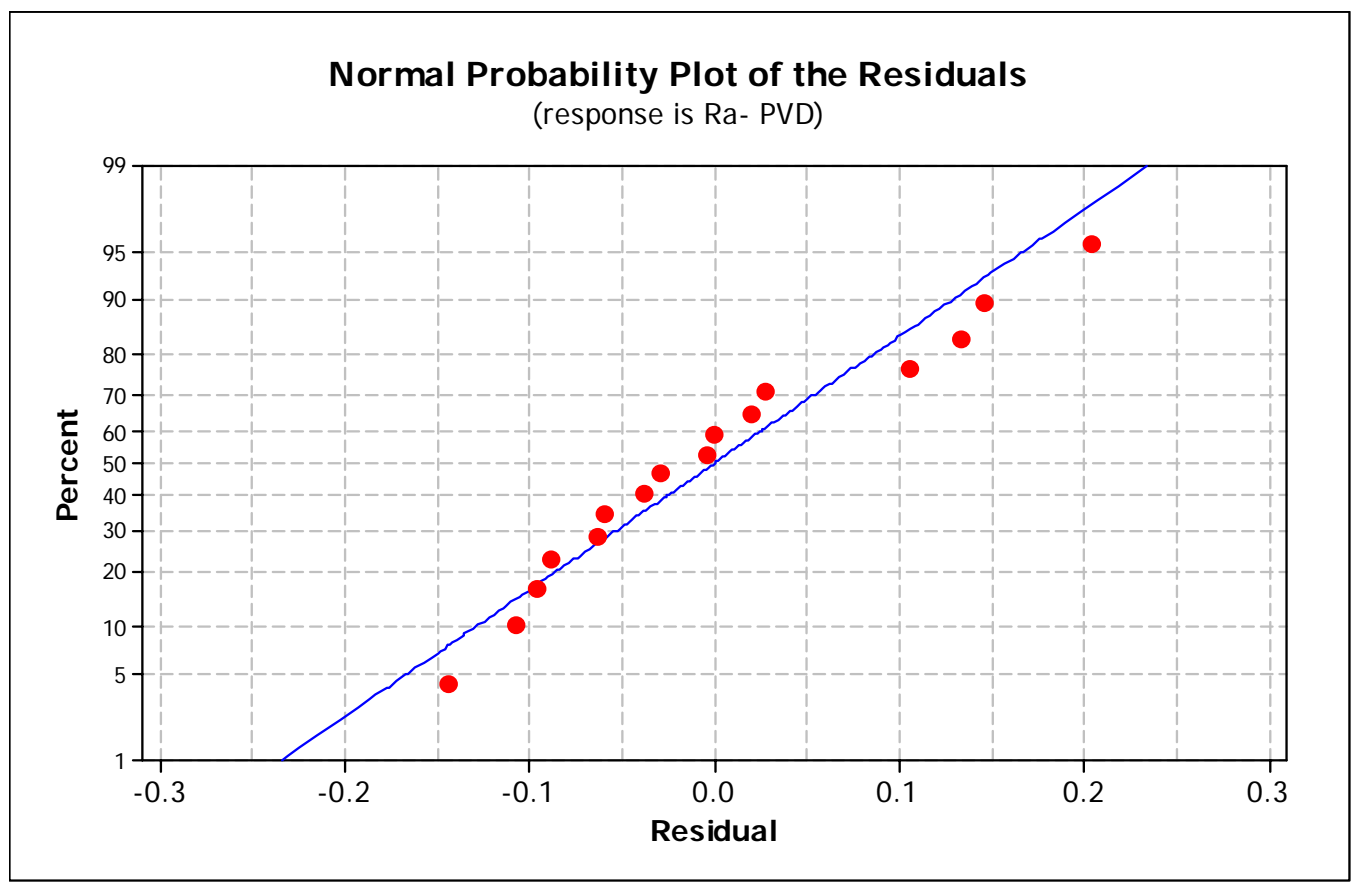

Figure 13: Normal Probability of the residuals for Surface roughness Values when turning with PVD insert (After data transformation)

\section{Conclusions}

The present work has been conducted to evaluate the coating material performance and determine the process parameters to optimize the surface roughness of AISI 304 austenitic stainless steel using PVD and CVD Coated cutting inserts. Taguchi technique is employed to determine the optimal levels of process parameters. The conclusions of the investigation can be drawn as follows:

- According to the coating types, the best surface finish is obtained for cutting by insert coated with TiAlN-TiN by PVD technique.

- The ANOVA and F-test revealed that the nose radius (62.88\%) is the dominant parameter when the turning is carried out by PVD insert. Cutting speed (37.83\%) is the significant factor when the material is turned by CVD insert. 
- The optimal combination of process parameters for obtaining minimum surface roughness values at $190 \mathrm{~m} / \mathrm{min}$ cutting speed, $0.25 \mathrm{~mm} / \mathrm{rev}$ feed, $0.5 \mathrm{~mm}$ depth of cut and $0.4 \mathrm{~mm}$ nose radius when turning with CVD insert. The optimal combination of process parameters for obtaining minimum surface roughness values at $170 \mathrm{~m} / \mathrm{min}$ cutting speed, 0.25 $\mathrm{mm} / \mathrm{rev}$ feed, $1.00 \mathrm{~mm}$ depth of cut and $0.4 \mathrm{~mm}$ nose radius when turning with PVD insert.

- The experimental results are different from theoretical tendency due to chip behavior during turning and complex deformation pattern of the work material.

- The optimal range of surface roughness values obtained are: $0.6718 \leq \bar{\mu}_{D_{1} C_{4}} \leq 1.184$ (When turning with CVD insert); $0.814 \leq \bar{\mu}_{C_{2} \mathrm{~A}_{2}} \leq 1.106$ (When turning with PVD insert)

- Multiple linear regression models were developed for surface roughness values of both the inserts. The developed models were reasonably accurate and can be used for prediction within limits. The optimal range of surface roughness values of the work piece is also predicted.

- The present work may be extended to study the influence of coatings on other responses like tool wear, tool tip temperature, tool vibration.

- The present work is carried out under dry environment. This work may be carried out under different cutting fluids.

\section{References}

Akasawa T., Sakurai H., Nakamura M., Tanaka T., Takano K., 2003. Effects of free-cutting additives on the machinability of austenitic stainless steels, Journal of Materials Processing Technology, Vol. 143/144, pp.66- 71.

Al-Ahmari A.M.A., 2007. Predictive machinability models for a selected hard material in Turning operations, Journal of Materials Processing Technology, Vol.190, pp.305-311.

Aman Aggarwal., Hari singh., Pradeep kuma., Manmohan singh., 2008. Optimizing power consumption for CNC turned parts using response surface methodology and Taguchi's Technique-A comparative analysis. Journal of Materials Processing Technology, Vol.200, pp.373-384.

Anirban Bhattacharya., Santanu Das., Majumdar P., Ajay Batish., 2009. Estimation of the effect of cutting parameters on surface finish and power consumption during high speed machining of AISI 1045 steel using Taguchi design and ANOVA, Production Engineering and Research Development, Vol. 3, pp.31-40.

Anthony Xavior M., Adithan M., 2009. Determining the influence of cutting fluids on tool wear and surface roughness during turning of AISI 304 austenitic stainless steel, Journal of Materials Processing Technology, Vol. 209, pp.900-909.

Basim A., Khidhirand., Bashir Mohamed., 2011. Analyzing the effect of cutting parameters on surface roughness and tool wear when machining nickel based hastelloy - 276, IOP Conf Series: Materials Science and Engineering, Vol. 17, doi:10.1088/1757 899X/17/1/012043.

Ciftci I., 2006. Machining of austenitic Stainless steels using CVD multi-layer coated cemented carbide tools, Tribology International, Vol.39, No. 6, pp. 565-569.

Endrino J.L., Fox-Rabinovich G.S., Gey C., 2006. Hard AlTiN, AlCrN PVD coatings for machining of austenitic stainless steel, Surface and Coatings Technology, Vol.200, pp.6840-6845.

Jahan M.P., Wong Y.S., Rahman M., 2010. A comparative experimental investigation of deep-hole micro-EDM drilling capability for cemented carbide (WC-Co) against austenitic stainless steel (SUS 304). International Journal of Advanced Manufacturing Technology, Vol. 46, pp.1145-1160.

Jindal P.C., Santhanam A.T., Schleinkofer U., Shuster A.F., 1999. Performance of PVD TiN, TiC, and TiAlN coated cemented carbide tools in turning, International Journal of Refractory Metals and Hard Materials, Vol.17, pp.163-170.

Korkut I., Kasap M., Ciftci I., Seker., 2004. Determination of optimum cutting parameters during machining of AISI 304 austenitic stainless steel, Materials and Design, Vol.25, pp.303-305.

Lin W.S., 2008. The study of high speed fine turning of austenitic stainless steel, Journal of Achievements in Materials and Manufacturing, Vol.27, pp.191-194.

Mahapatra S.S., Patniak A., Ku P., Patniak, 2006. Parametric analysis and optimization of cutting parameters for turning operations based on Taguchi method, Proceedings of the International Conference on Global Manufacturing and Innovation, Coimbatore, India, pp.1-8.

O’Sullivan D., Cotterell M., 2002. Machinability of austenitic stainless steel SS 303, Journal of Materials Processing Technology, Vol.124, pp.153-159.

Ozek. C., 2006. Turning of AISI304 austenitic stainless steel. Journal of Engineering and Natural sciences, Vol.2, pp.117-121.

Raju Shrihari Pawade and Suhas S. Joshi., 2011. Multi-objective optimization of surface roughness and cutting forces in highspeed turning of Inconel 718 using Taguchi grey relational analysis (TGRA), International Journal of Advanced Manufacturing Technology, DOI 10.1007/s00170-011-3183-z.

Ross P.J., 1996.Taguchi Techniques for Quality Engineering, McGraw-Hill Book Company,New York. 
Soderberg S., Sjostrand M., Ljungberg B., 2001. Advances in coating technology for metal cutting tools, Metal Powder Report, Vol.56, pp. 24-30.

Taha Z., Lelana H.-K., Aoyama H., Ariffin R., Ghazilla R., Gonzales J., Sakundarini N., Sutono S.B., 2010. Insert geometry effects on surface roughness in turning process of AISI D2 steel, Journal of Zhejiang University-SCIENCE A (Applied Physics and Engineering), Vol.11, No.12, pp.966-971.

Tian-syung Lan., 2009. Taguchi optimization of Multi objective CNC machinin using TOPSIS. International Technology Journal, Vol. 8, No.6, pp. 917-922.

Ulas Çaydas., Sami Ekici., 2010. Support vector machines models for surface roughness predictionin CNC turning of AISI 304 austenitic stainless steel. Journal of Intelligent Manufacturing, doi 10.1007/s10845-010-0415-2.

\section{Biographical notes}

M.Kaladhar graduated in Mechanical Engineering from SRKR College of Engineering, Bhimavaram, affiliated by Andhra University, India in 1994 and received his Master Degree in Industrial Engineering from College of Engineering,Trivandrum Kerala,India in 2004. He is presently working as an Assistant Professor in the Department of Mechanical Engineering in Praveenya Marine Engineering College Visakhapatnam, India. He is pursuing research at the Department of Mechanical Engineering, Andhra University,Visakhapatnam,India for his $\mathrm{PhD}$ Degree. He has published two research papers in international journals.

Dr. K. Venkata Subbaiah is a professor of Mechanical Engineering, College of Engineering, Andhra University, Visakhapatnam, India. Presently he is a Honorary Director, Andhra University Development Center. He served as Dean of Andhra University and Consulting Editor of Journal of Mechanical Engineering. He also served as Council member of The Institution of Engineers (India), Kolkata, Chairman and Honorary Secretary of The Institution of Engineers, Local Center. He published 48 papers in various National and International Journals and 23 papers in International/ National Conferences. His areas of Interests are Fuzzy Systems, Supply Chain Management, Inventory Management and Optimization.

Ch.Srinivasa Rao is currently an Associate Professor in the Department of Mechanical Engineering, Andhra University, Visakhapatnam, India. He graduated in Mechanical Engineering from SVH Engineering College, Machilipatnam,India in 1988. He received his Masters Degree From MANIT, Bhopal, India in 1991. He received $\mathrm{PhD}$ from Andhra University in 2004. He has published over 25 research papers in refereed journals and conference proceedings.

Received May 2011

Accepted June 2011

Final acceptance in revised form June 2011 